\title{
The Impact of Ulipristal Acetate (UPA) versus Dienogest on Pain Related to Endometriomas Evaluated with Visual Analogue Scale (VAS)
}

\author{
ROMINA MARINA SIMA DRAGOS ALBU², ANTONIU CRINGU IONESCUㄴ, MIHAI DIMITRIU³, MIHAI POPESCU,4, \\ DANA-RODICA TOMESCU ${ }^{4}$, RADU CHICEA ${ }^{5}$, IULIANA CEAUSU ${ }^{6}$, IOAN-IULIAN IORDACHE ${ }^{7}$, MIRCEA-OCTAVIAN POENARU ${ }^{1}$, \\ ALEXANDRA MATEI ${ }^{3}$, ALINA CALIN ${ }^{8 *}$, LIANA PLES ${ }^{1}$ \\ ${ }^{1}$ Carol Davila University of Medicine and Pharmacy, Department Obstetrics Gynecology, Bucur Maternity, St. John Hospital, 37 \\ Dionisie Lupu Str., 020021, Bucharest, Romania \\ ${ }^{2}$ Carol Davila University of Medicine and Pharmacy, Maternal-Foetal and Reproductive Medicine Department, Medlife, 37 \\ Dionisie Lupu Str., 020021, Bucharest, Romania \\ ${ }^{3}$ Carol Davila University of Medicine and Pharmacy, Department Obstetrics Gynecology, St Pantelimon Emergency Hospital, 37 \\ Dionisie Lupu Str., 020021,Bucharest, Romania \\ ${ }^{4}$ Carol Davila, University of Medicine and Pharmacy, Department of Anesthesiology and Critical Care III, Fundeni Clinical \\ Institute, 37 Dionisie Lupu Str., 020021,Bucharest Romania. \\ EUniversity of Medicine and Pharmacy Lucian Blaga, Faculty of Medicine, 10Victoriei Blvd.,550024, Sibiu, Romania. \\ ${ }^{6}$ Carol Davila University of Medicine and Pharmacy, Department Obstetrics Gynecology, Dr. I. Cantacuzino Hospital, 37 Dionisie \\ Lupu Str., 020021, Bucharest, Romania \\ ${ }^{7}$ Department of Gynecology and Obstetrics, Saarland University Hospital, Kirrbergerstraße 100, 66421, Homburg, Germany \\ ${ }^{8}$ Dunarea de J os University of Galati, 47 Domneasca Str, 800008, Galati, Romania
}

Visual analogue scale (VAS) is a psychometric scale applied to measure subjective characteristics. The purpose of our study was to evaluate the efficiency of Ulipristal acetate (UPA) compared with Dienogest for endometriomas related pain using VAS. We performed a randomized study on women with symptomatic endometriomas. The study was realized between January 2016-December 2018. The patients were randomized in two groups: Group A- that received UPA in doses of $5 \mathrm{mg}$ daily for 12-13 weeks and Group $B$ that received 2 mg Dienogest for 12-13 weeks. Each group received de VAS (Visual Analogue Scale) questionnaire before and after treatment. 70 women wereincluded in the study with 35 patients for each group. The age the mean age was 30.20 years. For Numeric Rating Scale before treatment in the group with UPA the median value was $6(\mathrm{Cl}=5.26,6.51)$ and for group $B$ the median was $5(\mathrm{Cl}=5.13,5.66)$. After treatment for group $A$ the median value was $4(C l=3.58,4.29)$ and for group $B$ the median value $4(C l=4.23$, 4.6). For FRS before treatment in the group with UPA median value was $6(C l=5.87,6.58)$ and for the group $B$ median was $6(C l=6.16,6.57)$. After treatment for group $A$ the median value was $4(C l=4.12,4.73)$ and for group $B$ the median value $5(C l=4.9,5.06)$. The pain significantly improved for group $A$. $(p<0.05)$ VAS represent a good method to evaluate the quality of pain for patients with endometriomas. The UPA and Dienogest treatment improve the VAS parameters with better results for UPA in the present study.

Keywords: endometriosis, VAS, dienogest, ulipristal, pain

Endometriosis is represented by ectopic implants of endometrial cells that cause local inflammatory response[1]. The pathogenesis is controversial but it includes altered immunity, aberrant endocrine signalling or genetic factors with six genomic regions affected[2]. Endometriosis treatment is medical or surgical. The medical classes used for endometriosis treatment are: nonsteroidal analgesics, gonadotropin-releasing hormone $(\mathrm{GnRH})$, agonists hormonal contraceptives and aromatase inhibitors. There is a lack of data to prove that one treatment or combination is better than another. The treatment is guided by symptom severity, treatment efficacy, medication side effects, contraceptive needs, costs, patient preferences and availability[3].

It was observed that for women with pelvic pain caused by endometriosis or for the ones who have contraindications for combined estrogen-progestin contraceptives, progestin-only represents a good treatment option. The most used progestins administered for the treatment of endometriosis-related pain are medroxyprogesteroneacetate norethindrone acetate and
Dienogest[4]. In recent systematic reviews aboutprogestin therapy for endometriosis Dienogest was superior to placebo[5].

Progesterone receptors antagonists were used in the early 1990 by Philibert et al as contraceptive drugs and nowadays there is produced a wide spectrum of similar drugs with PR (progesterone receptor) agonist and antagonisteffects[ 6]. Ulipristal acetate (UPA) is introduced and approved since 2009 for leiomyomas treatment and contraceptive reasons by the EMA (European Medicines Agency) and in 2010 by FDA (U.S. Food and Drug Administration). UPA is a dose dependent PR antagonist and agonist with impact on endometrium and myometrium. It acts as PR antagonist with contraceptive effect, also inunique administration (emergency contraception) [7]. Lately the therapeutic indication of UPA wereextended to endometriosis as well.

The therapeutic response for endometriosis use is related to symptoms reduction and quality of life improvement. For quality of life and evaluation there are many standard questionnaires. Among those visual 
analogue scales (VAS) are psychometric scales applied to measure subjective characteristics. At the beginning they were used for different types of disorders, and for research and social investigationspurpose[8]. We performed a randomized study about the efficiency of UPA compared with dienogest for endometriomas related pain using VAS.

\section{Experimental part}

A randomized study was conducted on women with symptomatic endometriomas. The study is multicentre centre study, extended between January 2016-December 2018. Ethical approval and patient's informed consent for treatment and study were obtained.

The study included women with symptomatic endometriomas that received conservative management. Transvaginal ultrasound was performed by two experienced sonographists and the endometriomas were measured and mapped. It was considered only the largest diameter of the endometrioma and in order to reduce biasses the same doctor evaluated the same patient at the beginning and at the end of the treatment.

The inclusion criteria were: women with symptomatic endometriomas, that involved one or both ovaries, the endometriomas dimension under $5 \mathrm{~cm}$ and patients that agreed with the study. Exclusion criteria were: patients who didn't accept the study, other types of endometriosis such as deep infiltrative endometriosis, endometriomas with diameters over $5 \mathrm{~cm}$ that had indication for surgical approach.

A randomized controlled study was designed. The patients were randomized from the beginning in two groups: Group A- that received UPA in doses of $5 \mathrm{mg}$ daily starting with the first or second menstrual day for 12-13 weeks and Group B that received $2 \mathrm{mg}$ Dienogest starting with the first or second menstrual day for 12-13 weeks. Each group received de VAS (Visual Analogue Scale) questionnaire before and after treatment.

The randomization was made according to seal envelope method. The patient signed the inform and then the patient selected a sealed envelope from a pile opened it in front of the person that was in charge for recruiting patients for the trial. Then the patient was distributed in

\begin{tabular}{|l|l|l|}
\hline Group characteristics & & \\
\hline Age [years] & 30,20 years (mean) & (min:18 years, max 42 years, std dev:5.78) \\
\hline Endometrioma dimension & $3.63 \mathrm{~cm}$ (mean) & (min:2 cm, max 4.7 cm, std dev:0.66) \\
before treatment [mm] & & \\
\hline Endometrioma dimension after & $39 \mathrm{~cm}$ (mean) & (min: $1.8 \mathrm{~cm}, \max 4.5 \mathrm{~cm}$, std dev:0.67) \\
treatment [mm] & & No $27.1 \%$ \\
\hline Dyspareunia & & No $28.6 \%$ \\
\hline Dysmenorrhea & & No $45.7 \%$ \\
\hline Previous operations & Yes $71.4 \%$ & No $25.7 \%$ \\
\hline Quality of life improvement & Yes $74.3 \%$ & \\
\hline
\end{tabular}

one of the categories. The physicianshow performed the ultrasound scan were blinded. Patients were informed about their treatment and signed the informed consent. The statistician was informed that there were 2 groups: A and $B$. He did nothave any information regarding the patient treatment. At the end of the treatment courses the patients were examined by ultrasound and filled VAS questionnaire.

Statistical analysis was carried out with Statistical Package for Social Sciences (SPSS) Software 25.0. The differences between the treatment groups were evaluated by One Way ANOVA and t-test. Data were expressed as mean \pm standard deviation (std dev). Pearson's correlation was used as appropriate and two-sided $p$-values of $<0.05$ were considered to indicate statistical significance.

\section{Results and discussions}

A group of 70 women was randomized in our study with 35 patients for each group. The main group characteristics for the entire study group are illustrated in Table 1. The age of the patients included in the study group varied between 18 and 42 years, the mean age being 30.20 years. Clincial symptoms severity, timing and all other significant information related to endometriosis were obtained. History of each patient was obtained and it revealed that $54.3 \%$ of the patients from the whole study group had previous surgical interventions for endometriosis. The main complains were dyspareunia, dysmenorrhea as reported in Table 1. Overall the patients described an altered quality of life dueto endometriosis symptoms but it improved in $74.3 \%$ cases after treatment. For UPA group $80 \%$ patients admitted that quality of life improved whereas $68.6 \%$ patients from Dienogest group described such association.

All the patients underwent ultrasound examination. Regarding endometriomas distribution it was observed that $37.1 \%$ involved the right ovary, $42.9 \%$ affected the left ovary and $20 \%$ were bilateral. It was identified that before treatment the mean endometrioma dimension was 3.63 $\mathrm{cm}$ and decreased to the mean dimension of $3.49 \mathrm{~cm}$ ( $p<$ 0.001 ) for the entire study groups. Endometriomas dimensions diminutionafter UPA and Dienogest treatment $(p<0.001)$ isdetailed in table 2.
Table 1

THE STUDY GROUP CHARACTERISTICS 


\begin{tabular}{|c|c|c|c|c|c|c|}
\hline \multirow{2}{*}{\multicolumn{2}{|c|}{ group }} & \multirow[b]{2}{*}{$\mathrm{t}$} & \multirow{2}{*}{$\begin{array}{l}\text { Sig. } \\
\text { tailed })\end{array}$} & \multirow{2}{*}{$\begin{array}{l}\text { Mean Differ- } \\
\text { ence }\end{array}$} & \multicolumn{2}{|c|}{$\begin{array}{l}95 \% \text { Confidence Interval of } \\
\text { the Difference }\end{array}$} \\
\hline & & & & & Lower & Upper \\
\hline \multirow[t]{2}{*}{ UPA } & dimension1 & 28.194 & .000 & 3.31143 & 3.0727 & 3.5501 \\
\hline & dimension2 & 27.292 & .000 & 3.15143 & 2.9168 & 3.3861 \\
\hline \multirow[t]{2}{*}{ dienogest } & dimension1 & 51.990 & .000 & 3.96000 & 3.8052 & 4.1148 \\
\hline & dimension2 & 49.574 & .000 & 3.83429 & 3.6771 & 3.9915 \\
\hline
\end{tabular}

Table 2

THE DIMENSION OF ENDOMETRIOMAS BEFORE AND AFTER TREATMENT
The main purpose of the present study was to characterize the pain associated to endometriomas. To the first point of the scale (Option 1) with 10 points for no paint and 0 points for worst pain ever it is observed from images 1 ( $a$ and $b$ ) the characteristics of pain before and after treatment. Before treatmentin the group with UPA the median value was $4(\mathrm{Cl}=3.75,4.64)$ and for the group $\mathrm{B}$ the median was $5(\mathrm{Cl}=4.22,4.97)$. After treatment for group A the median value was $6(\mathrm{Cl}=5.33,6.28)$ and for group $B$ the median value $6(\mathrm{Cl}=5.38,5.93)$. The pain significantly improved for group $A(p<0.001)$ (fig. $1 a, b)$.
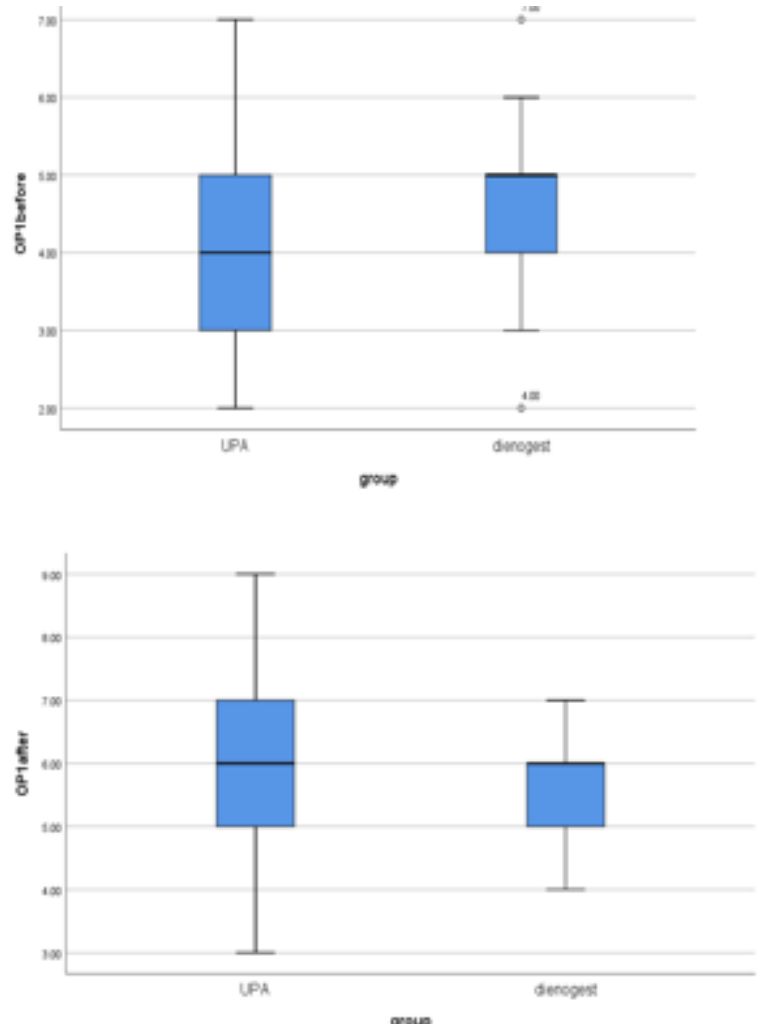

Fig. 1 (a, b): Option 1 before and after treatment

For the second point of the scale (Option 2) with 10 points for worst pain ever and 0 points for no paint it is observed from images 2 ( $a$ and $b$ ) the characteristics of pain before and after treatment. Before treatment in the group with UPA the median value was $6(\mathrm{Cl}=5.29,6.18)$ and for group $B$ the median was $6(\mathrm{Cl}=5.11,5.85)$. After treatment for group A the median value was $4(\mathrm{Cl}=3.6$, 4.39) and for group $B$ the median value $5(\mathrm{Cl}=4.26,4.93)$. The pain significantly improved for group $A(p<0.001)$ (fig. $2 a, b)$.

For the third point of the scale (NRS-Numeric Rating Scale) with 10 points for worst possible pain and 0 points
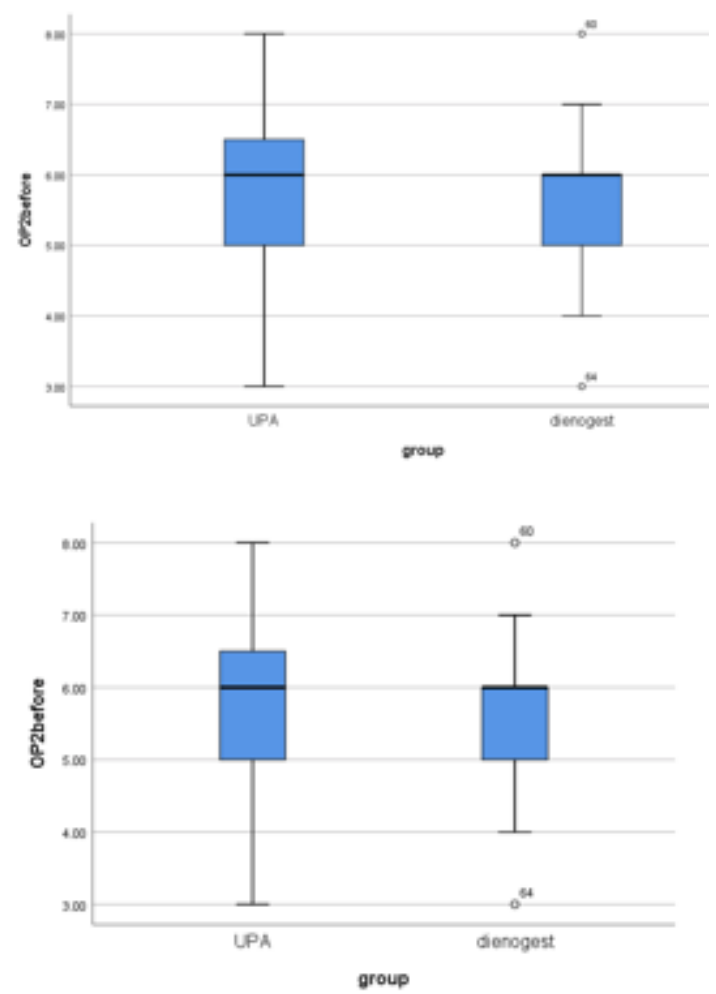

Fig. $2(\mathrm{a}, \mathrm{b})$ : Option 2 before and after treatment

for no pain it is observed from images 3 ( $a$ and $b$ ) the characteristics of pain before and after treatment. Before treatment in the group with UPA the median value was 6 $(\mathrm{Cl}=5.26,6.51)$ and for group $\mathrm{B}$ the median was $5(\mathrm{Cl}=$ $5.13,5.66)$. After treatment for group $A$ the median value was $4(\mathrm{Cl}=3.58,4.29)$ and for group $B$ the median value 4 $(\mathrm{Cl}=4.23,4.6)$. The pain significantly improved for group $\mathrm{A}$ $(p<0.001)$ (fig. $3 a, b)$.

For the fourth point of the scale (FRS-Face Rating Scale) with 10 points for hurts and 0 points for no hurtit is observed from images 4 ( $a$ and $b$ ) the characteristics of pain before and after treatment. Before treatment in the group with UPA median value was $6(\mathrm{Cl}=5.87,6.58)$ and for the group $\mathrm{B}$ median was $6(\mathrm{Cl}=6.16,6.57)$. After treatment forgroup A the median value was $4(\mathrm{Cl}=4.12,4.73)$ and for group $\mathrm{B}$ the median value $5(\mathrm{Cl}=4.9,5.06)$. The pain significantly improved for group A ( $p<0.001$ )(fig. $4 a, b)$.

Functional Activity Score (FAS) was also evaluated before and after treatment. It can be observed from Table 3 that there was significant improvement of activity because of endometriosis treatment. The group A had mild limitation of activity in $88.6 \%$ cases and $11.4 \%$ cases before UPA administration. For group $B$ the limitation of activity was severe for $85.7 \%$ cases and mild for $14.3 \%$ cases and after Dienogest administration the limitation was severe 

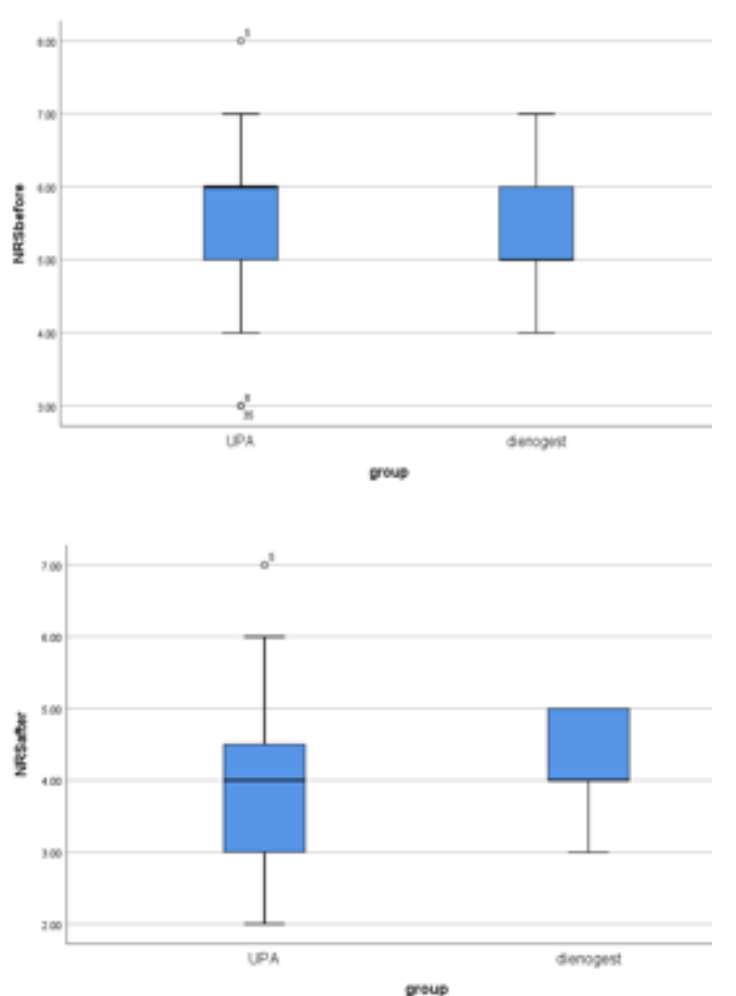

Fig. $3(a, b)$ : NRS before and after treatment

for $68.6 \%$ and remained severe for $31.4 \%$ cases. Overall the treatment improved the activity for patients with endometriosis but UPA was more efficient in this study (table 3).

VAS was first introduced in 1921 and it was initiated as a graphic rating method [9]. It is considered that the main advantage of this method is that it offers the possibility to evaluate detailed subtypes of judgement of the patient. It also requires the patient hand-eye coordination and visual ability[ 10]. The most important disadvantage is that it can be used in written (or digital) format and not for oral interviews and considerable effort for data entry and statistical analysis [11].This is the first study that compare the therapeutic effect of UPA and Dienogest in endometriosis related symptoms evaluated using VAS. In the present study we observed that overall both UPA and Dienogest ameliorate the pain for patients with endometriomas. There are significant changes regarding dysmenorrhea (from 72.9 to $27.1 \%$ ), dyspareunia (from 71.4 to $28.6 \%$ ) and quality of life improvement dyspareunia (from 74.3 to $25.7 \%$ ). The parameters of VAS suffered significant changes after treatment. It was identified that UPA and Dienogest improved pain with impact on numeric
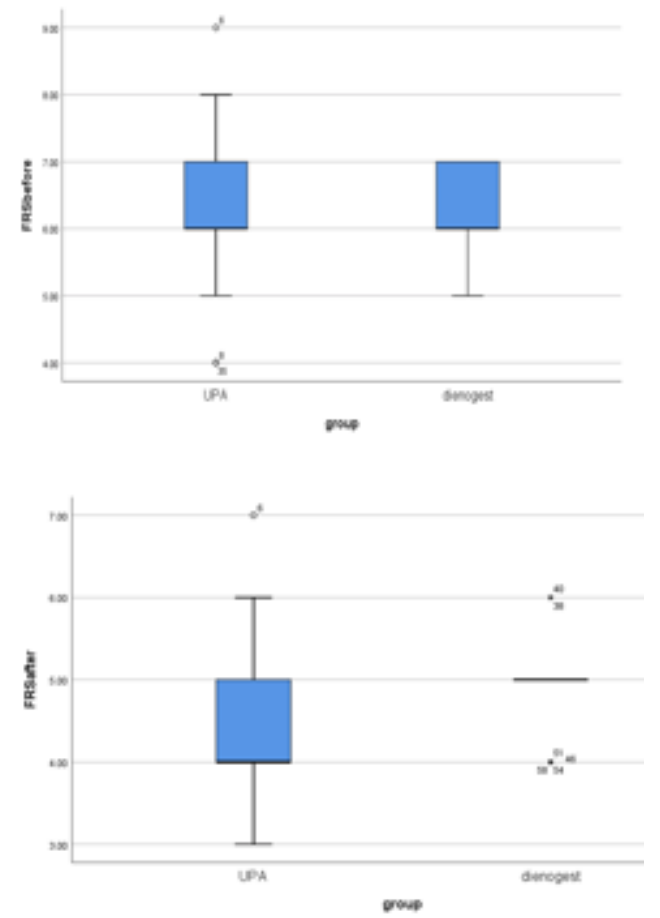

Fig. $4(a, b)$ : FRS before and after treatment

rating scale and face rating scale, but UPA results were superior to Dienogest results. The pain significantly improved for group A. $(p<0.05)$

The purposes of endometriomas treatment are to removethe symptoms as pain, to reduce the tumor dimensions, to improve subfertility or to avoid and prevent complications such as the cyst rupture or torsion. It was observed that medical therapy did not resolve endometriomascompletely[12]. Symptomatic or rapidly increasing endometriomas are treated laparoscopically. It was proved that laparoscopy improves the quality of life and sexual function after different procedures in pelvic area such myomectomy[ 13] and for all types of endometriosis with laparoscopic approach $[14,15]$. The most important disadvantage of endometriomas surgical removal is that the ovarian reserve diminish with each procedure. For ovarian protection reserve, asymptomatic and small ovarian endometriomas $(\leq 5 \mathrm{~cm})$ can benefitfrom medical approach [16].

Estrogen expresion suppression and progesterone receptors activation represent the essential target for current drugs, and also for research and new drugs development. The most used and studied agents for

\begin{tabular}{|c|c|c|c|c|c|c|}
\hline \multicolumn{3}{|l|}{ group } & $\begin{array}{c}\text { Frequency } \\
\text { after }\end{array}$ & $\begin{array}{l}\text { Percent } \\
\text { after }\end{array}$ & $\begin{array}{c}\text { Frequency } \\
\text { before }\end{array}$ & $\begin{array}{l}\text { Percent } \\
\text { before }\end{array}$ \\
\hline \multirow[t]{4}{*}{ UPA } & \multirow[t]{4}{*}{ Valid } & no limitation & 1 & 2.9 & 0 & 0 \\
\hline & & mild limitation & 25 & 71.4 & 31 & 11.4 \\
\hline & & severe limitation & 9 & 25.7 & 35 & 88.6 \\
\hline & & Total & 35 & 100.0 & 5 & 100.0 \\
\hline \multirow[t]{3}{*}{ Dienogest } & \multirow[t]{3}{*}{ Valid } & mild limitation & 24 & 68.6 & 4 & 14.3 \\
\hline & & severe limitation & 11 & 31.4 & 31 & 85.7 \\
\hline & & Total & 35 & 100.0 & 100.0 & 100.0 \\
\hline
\end{tabular}

Table 3

FAS SCORE BEFORE AND AFTER TREATMENT 
endometriosis treatment are oral GnRH antagonists, aromatase inhibitors SERMs ( Selective Estrogen Receptors Modulators) and SPRMs [17-19]. UPA is generally prescribed for conservative treatment of fibroids to preserve fertility. UPA was approved treatment for uterine fibroids since 2012. The action on the myometrium are antiproliferative, antifibrotic and proapoptotic with reduction a fibroid volume reduction to up 45\%[20]. UPA effect is safe for endometrium[21].

The clinical effects of Dienogest for endometriosis treatment are reported in different studies and it was observed that it reduces the size of endometriomas and determine symptome relief for women with recurrent endometriosis [22]. Dienogest is efficient and safe for management of endometriosis associated pelvic pain[23] and avoidpain recurrence post surgery. Dienogest is well tolerated and side effects can be clinically managed [24]. Vaginal treatment with dienogest is innovative for symptomatic deeply infiltrating rectovaginal endometriosisand should receive further investigation in pharmacokinetic and clinical studies [25]. On the ovary, Duphaston and Dienogest are effective progestins that can be used as oral contraceptivewith different ovulation inhibitory effects [26,27]. The ovulation inhibitory effect induced by Dienogest could be reverse rapidly by stopping treatment $[28,29]$. Studies demonstrated the beneficial effect on pain generated by cyst endometrioma[30]. Side effects of progestin are represented by irregular uterine amenorrhea (dienogest), mood changes (depression) weight gain, and bone loss[31].

UPA and Dienogest are proved to be effective as antiendometriosis drugs inducing apoptosis and reducing proliferation and adhesions. UPA and Dienogest are very well tolerable by the patient. For Dienogest use endometrial glandular hyperplasia was described and, follicle accumulation for UPA[32]. Ulipristal acetate can control irregular bleeding by inducing amenorrhea while Dienogest may cause irregular uterine bleeding[33,34].

This study is a pilot research that compares the effects of UPA versus Dienogest insymptomatic patients with endometriomas evaluated by VAS. The strength of our study is represented by the accuracy of the protocol with good applicability before and after treatment. The limitation of the study is the reduced number of patients.

\section{Conclusions}

VAS represent a good method to evaluate the quality of pain for patients with endometriomas. The UPA and Dienogest treatment improve the VAS parameters with better results for UPA in the present study. Further research is needed aiming also other administration ways (vaginal) and on larger patients cohorts to asses the benefits and the safety of UPA in endometriosis.

Acknowledgement:This work was supported by University of Medicine and Pharmacy Carol Davila a project number 5781/08.03.2018

\section{References}

1.GIUDICE LC. Clinical practice. Endometriosis. N Engl J Med 2010; 362:2389.

2.RAHMIOGLU N, NYHOLT DR, MORRIS AP, ET AL. Genetic variants underlying risk of endometriosis: insights from meta-analysis of eight genome-wide association and replication datasets. Hum Reprod Update 2014; 20:702.

3.DUNSELMAN GA, VERMEULEN N, BECKER C, et al. ESHRE guideline: management of women with endometriosis. Hum Reprod 2014; 29:400.
4.Practice Committee of the American Society for Reproductive Medicine. Treatment of pelvic pain associated with endometriosis: a committee opinion. Fertil Steril 2014; 101:927.

5.BROWN J, KIVES S, AKHTAR M. Progestagens and anti-

progestagens for pain associated with endometriosis. Cochrane Database Syst Rev 2012; :CD002122.

6.PHILIBERT D, RU38486: An original multifaceted anti hormone in vivo. In Agarwal M (ed.) Adrenal Steroid Antagonism. Walter de Gruyter and Co, Berlin, 1984; 77-101.

7.CHABBERT-BUFFET N, MEDURI G, BOUCHARD P, SPITZI. Selective progesterone receptor modulators and progesterone antagonists: mechanisms of action and clinical applications. Human Reproduction Update,2005; 11(3) : 293-307.

8.FLYNND, VANSCHAIKP, VANWERSCHA.Acomparison ofmultitem likert and visual analogue scales for the assessment of transactionally defined coping. Eur J Psychol Assess. 2004;20:49-58.

9.HAYESMHS, PATERSON DG. Experimental development of thegraphic ratingmethod. PsycholBull. 1921;18:98-9.

10.DUNCAN GH, BUSHNELL MC, LAVIGNE GJ. Comparison of verbal and visual analogue scales for measuring the intensity and unpleasantness of experimental pain. Pain. 1989;37:295-303.

11.KRAUTH J. Testkonstruktion und Testtheorie. Weinheim: BeltzPVU;1995.

12.CHAPRON C, VERCELLINI P, BARAKAT H, ET AL. Management of ovarian endometriomas. Hum Reprod Update 2002; 8:591.

13.RADOSA J C, RADOSA CG, MAVROVA R, WAGENPFEIL S, HAMZA A, JOUKHADAR R, BAUM S, KARSTEN M, JUHASZ-BOESS

I, SOLOMAYER EF, RADOSA MP. Postoperative Quality of Life and Sexual Function in Premenopausal Women Undergoing Laparoscopic Myomectomy for Symptomatic Fibroids: A Prospective Observational Cohort Study. PLoS One. 2016 Nov 29;11(11):e0166659.

14.ARCOVERDE FVL, ANDRES MP, BORRELLI GM, BARBOSA PA, ABRAO MS, KHO RM.Surgery for Endometriosis Improves Major Domains of Quality of Life: A Systematic Review and Meta-Analysis.J Minim Invasive Gynecol. 2018 Sep 20. pii: S1553-4650(18)31244-5.

15.BADIU DC, SIMA RM, MEHEDINTU C, MASTALIERB, MANDU M, ANDRONACHE LF, PADURARU DN, STOIAN AP, GRIGOREAN VT. Abdominal-pelvic pain in female patients with endometriosis - a review of the literature. J Mind Med Sci. 2018; 5(2): 158-162.

16.RAFFI F, METWALLY M, AMER S. The impact of excision of ovarian endometrioma on ovarian reserve: a systematic review and metaanalysis. J Clin Endocrinol Metab 2012; 97:3146.

17.CLEMENZA S, SORBI F, NOCI I, CAPEZZUOLI T, TURRINI I, CARRIERO C, BUFFI N, FAMBRINI M, PETRAGLIA F.From pathogenesis to clinical practice: Emerging medical treatments for endometriosis. Best Pract Res Clin Obstet Gynaecol. 2018 Aug;51:92-101.

18.DUCEAC, L.D., LUCA, A.C., MITREA, G., BANU, E.A., CIUHODARU, M.I.,CIOMAGA, I., ICHIM, D,L., BACIU, G., Ceftriaxone Intercalated Nanostructures Used to Improve Medical Treatment. Mat. Plast., 55, no.4, 2018, p.613-615

19.LUCA, A.C., DUCEAC, L.D., MITREA, G., CIUHODARU, M.I., ICHIM, D.L, BACIU, G., BANU, E.A., IORDACHE, A.C., Antibiotic Encapsulated Nanomaterials with Application in Medical Area. Mat. Plast., 55, no.4, 2018, p.552-554.

20.DONNEZ J, TATARCHUK TF, BOUCHARD P, PUSCASIU L, ZAKHARENKO NF, IVANOVA T, IVANOVAT, UGOCSAI G, MARA M, JILLA MP, BESTEL E, TERRILL P, OSTERLOH I, LOUMAYE E; PEARL I Study Group. Ulipristal acetate versus placebo for fibroid treatment before surgery. N Engl J Med, 2012, 366(5):409-420.

21.PLES L, SIMA RM, CARP D, FLORESCU C, DIMITRIU MCT, IONESCU CA.UPA effects on endometrium - what is the significance?Rom J Morphol Embryol. 2018;59(4):1127-1132.

22.LEE JH, SONG JY, YI KW, LEE SR, LEE DY, SHIN J H, CHO S, SEO SK, KIM SH. Effectiveness of Dienogest for Treatment of Recurrent Endometriosis: Multicenter Data. Reprod Sci. 2018 Oct;25(10):1515-1522. 
23.YU Q, ZHANG S, LI H, WANG P, ZVOLANEK M, REN X, DONG $L$, LANG J.Dienogest for Treatment of Endometriosis in Women: A 28-Week, Open-Label, Extension Study. J Womens Health (Larchmt). 2019 Feb;28(2):170-177.

24.ROMER T.Long-term treatment of endometriosis with dienogest: retrospective analysis of efficacy and safety in clinical practice. Arch Gynecol Obstet. 2018 Oct;298(4):747-753.

25.EBERT AD.Daily Vaginal Application of Dienogest (Visanne $\odot)$ for 3Months in Symptomatic Deeply Infiltrating Rectovaginal Endometriosis: A Possible New Treatment Approach? Case Rep Obstet Gynecol. 2018 May 10;2018:8175870.

26.ENDRIKAT J, PARKE S, TRUMMER D, SERRANI M, DUIJ KERS I, KLIPPING C. Pituitary, ovarian and additional contraceptive effects of an estradiol-based combined oral contraceptive: results of a randomized, open-label study. Contraception. 2013;87:227-34.

27.IONESCU C.A, NAVOLAN D, CALIN A, MATEI A, BOHILTEA R, DIMITRIU M, ILINCA C, PLESL. Hormonal Contraception in Postpartum Patients with Gestational Diabetes Mellitus. Rev.Chim.(Bucharest), 69, no 2, 2018, p.478-483.

28. KLIPPING C, DUIJ KERS I, REMMERS A, FAUSTMANN T, ZURTH C, KLEIN S, SCHUETT B. Ovulation-inhibiting effects of dienogest in a randomized, dose-controlled pharmacodynamic trial of healthy women. J Clin Pharmacol. 2012;52:1704-13.
29. PACU I, IONESCU C.A, VLADAREANU S, BANACU M, NEACSU A, CALIN A. Predictive value of the AMH Level and serum estradiol for ovarian hyperstimulation syndrome in the assisted human reproduction. Rev.Chim.(Bucharest), 68, no 5, 2017, p.1118-1121

30.IONESCU C, MATEI A, NAVOLAN D, DIMITRIU M, BOHILTEA R, NEACSU A, ILINCA C, PLES L . Correlation of ultrasound features and the risk of ovarian malignancy algorithm score for different histopathological subtypes of benign adnexal masses. Medicine vol 97 issue 31 August 2018 e11762

31.CIRKEL U, SCHWEPPE KW, OCHS H, ET AL. Effects of LHRH agonist therapy in the treatment of endometriosis. In: Gonadotropin Downregulation in Gynecological Practice, Chadha DR, Willemsen WNP (Eds), Aln R Liss, New York 1986. Vol 25, p.189

32.LIANG B, WU L, XU H, CHEUNG CW, FUNG WY, WONG SW, WANG CC.Efficacy, safety and recurrence of new progestins and selective progesteronereceptor modulator forthe treatment of endometriosis: a comparison study in mice. Reprod Biol Endocrinol. $2018 \mathrm{Apr}$ 3;16(1):32

33.DONNEZ J , HUDECEK R, DONNEZ O, MATULE D, ARHENDT H-J, ZATIK J, KASILOVSKIENE Z, DUMITRASCU MC, FERNANDEZ H, BARLOW DH, ET AL. Efficacy and safety of repeated use of ulipristal acetate in uterine fibroids. Fertil Steril. 2015;103:519-27. e513

34.MICKSEA, JENSEN JT. Treatment of heavy menstrual bleeding with the estradiol valerate and dienogest oral contraceptive pill. Adv Ther. 2013;30:1-13

$\overline{\text { Manuscript received } 22.09 .2018}$ 